\title{
Positive Deviance as a Mediator in the Relationship Between High Performance Indicators and Entrepreneurial Orientation
}

\author{
Przemysław Zbierowski
}

\begin{abstract}
A B S T R A C T
Objective: The purpose of the article is to investigate positive deviance as a mediator in the effect of high performance indicators on organisational entrepreneurship.

Research Design \& Methods: The research was carried out on a representative and random sample of 406 enterprises using multi-source cross-sectional design. The main analytical technique is structural equations modelling.

Findings: The impact of high performance indicators on positive deviance is somehow ambiguous. Some of the factors influence positive deviance in a positive way (continuous improvement, openness and action orientation, management quality) and some in a negative way (workforce quality, long-term orientation). Positive deviance has a positive effect on all three dimensions of entrepreneurial orientation. However, rather unexpectedly, the effect is the weakest for innovativeness. The study revealed general indirect effect of high performance factors on dimensions of entrepreneurial orientation with the mediation of positive deviance.
\end{abstract}

Implications \& Recommendations: The study has implications for research and practice. It partly explains the effects of high performance indicators for organisational entrepreneurship. Companies that are in pursuit of higher organisational entrepreneurship can use it as a good way of supporting it.

Contribution \& Value Added: The study contributes to research on high performance and entrepreneurship mainly by drawing attention to positive deviance as a mediator in the effect of high performance factors on organisational entrepreneurship.

\begin{tabular}{|c|c|c|}
\hline Article type: & \multicolumn{2}{|l|}{ research article } \\
\hline Keywords: & \multicolumn{2}{|c|}{$\begin{array}{l}\text { high performance organisation; entrepreneurial orientation; positive } \\
\text { deviance }\end{array}$} \\
\hline JEL codes: & L26 & \\
\hline Received: 6 November 2018 & Revised: 21 Match 2019 & Accepted: 1 April 2019 \\
\hline
\end{tabular}

\section{Suggested citation:}

Zbierowski, P. (2019). Positive Deviance as a Mediator in the Relationship Between High Performance Indicators and Entrepreneurial Orientation. Entrepreneurial Business and Economics Review, 7(2), 217-233. https://doi.org/10.15678/EBER.2019.070212 


\section{INTRODUCTION}

High organisational performance is one of the end results that are investigated in management science (De Waal, 2012). Scholars and practitioners for decades have tried to unlock the mystery of extraordinary outcomes and answered the question why some organisations are extremely successful while others fail. One of the most coherent frameworks of high performance indicators has been presented by De Waal (2012). However, the author claims that it only answers the question 'what' high performers do to be successful and not 'how' they do it. Therefore, the article is placed in the research stream that attempts to uncover the mechanism underlying the activities of market leaders. The study argues that a lot of explanation in that regard could be proposed by another dynamic research notion - positive organisational scholarship (POS). It draws attention to phenomena that are normatively positive and extraordinarily effective. One of the most interesting of them is positive deviance. Therefore, this study examines its role in organisational processes and the purpose of the article is to investigate if positive deviance is the mediator in the relationship between high performance indicators and organisational entrepreneurship. The reason behind the choice to include the latter construct is twofold. That relationship was researched previously only in direct manner and organisational entrepreneurship (conceptualised as entrepreneurial orientation) has been positively linked to high performance.

To test the mediation effect the present study uses the random and representative sample of 406 organisations and test the hypotheses using structural equations modelling. The research is novel in its approach to putting positive deviance at the heart of high performance processes within the organisation. The contribution that it is trying to make is threefold. First, it explains the way in which positive deviance has effect on organisational entrepreneurship processes within an organisation. Second, it contributes to entrepreneurial orientation literature by explaining its antecedents. Finally, it contributes to high performance organisation literature by answering the question how high performance characteristics create the actual organisational performance. The research was carried out within the research project 2014/13/B/HS4/01618 funded by the National Science Centre, Poland.

\section{LITERATURE REVIEW}

\section{High Performance Organisation}

The beginning of the notion of a high performance organisation might be dated back to the early 1980s. Perhaps the first publication that can be entirely placed within that notion is the work by Peters and Waterman (1982). It describes the behaviours of most successful American companies. Peters and Waterman (1982) discovered that they share a couple of common phenomena: action orientation, being close to the customer, autonomy and entrepreneurship, productivity thanks to employees, strong values, a clear profile of activity, a simple form and low employment and reconciling the contradiction between centralising and decentralising. Moreover, the key aspect that Peters and Waterman (1982) highlight is organisational alignment.

Other significant contributions to the notion that have to be mentioned are by Collins and Porras (1994) and Collins (2001). Collins and Porras (1994) state that there are nine factors that distinguish leaders from other companies: continuity and change, key values 
and mobilising goals, stability and non-linearity, 'cult' culture and specific people, consequence and innovations, discipline and creativity, systematic methods and experimental approaches, meaning and achievements, maintaining the core activities and stimulation of growth. The notion of a high performance organisation was later continued by Holbeche (2005), Light (2005), Miller and Le Breton-Miller (2005), Lawler and Worley (2006). For instance, Light (2005) presents the list of four main traits of successful organisations: (1) alertness achieved by thinking in future terms, (2) agility in empowering members of the organisation achieved by supporting communication and organising, (3) adaptation achieved by building freedom in learning and imagination, using all available measures to avoid lack of precision, (4) alignment achieved by leading towards vision and mission.

All of the above considerations are however not methodologically robust, they lack a clear methodological approach. Moreover, the considerations of various authors are not consistent in their approaches, which makes it difficult to compare the results of their research (Peters \& Waterman, 1982; Collins \& Porras, 1994). The above limitations were taken into consideration by De Waal (2012) who proposed a coherent framework of 35 high performance indicators grouped within five high performance factors that are described below.

'Continuous improvement' includes adopting a strategy that sets the organisation apart from others. Moreover, the organisation makes a constant effort to develop, the organisation's processes are continuously improved, simplified and aligned. For continuous improvement, it is also important that everything that matters to performance is explicitly reported and both financial and non-financial information is reported to organisational members (De Waal, 2012, p. 34). Finally, for continuous improvement it is important to constantly innovate, high performers continuously innovate their competencies, products, processes and services (De Waal, van Nierop, \& Sloot, 2017).

'Openness and action orientation' is the factor that stresses the constant drive towards activity and performance (De Waal, 2010, p. 87). For that reason, the whole organisation must be performance-driven. It is based on a frequent dialogue of the management with the employees. Organisational members spend a lot of time on communication, knowledge exchange and learning. Moreover, they are always involved in important processes. Openness and action orientation also require certain style from the management (De Waal \& Heijtel, 2017) - managers must allow employees to make mistakes and welcome change.

The style of leadership is more broadly described in the 'management quality' factor. In high performing organisations leaders have integrity, they are role models for organisational members (De Waal, 2012, p. 33). Moreover, they are fast both in decision making and taking a necessary action. Leaders are very effective, but they also focus on achieving results and coach organisational members to do the same. Leaders are also decisive with regard to nonperformers (De Waal, van Nierop, \& Sloot, 2017). Leadership in high performing organisations is strong, leaders are confident and are trusted by organisational members.

Management quality is also reflected in 'workforce quality' (De Waal \& Meingast, 2017). That is achieved by holding organisational members responsible for their results. Management inspires organisational members to accomplish extraordinary results, organisational members are trained to be resilient and flexible and the organisation has diverse and complementary workforce (De Waal \& Heijtel, 2017).

Finally, high performing organisations are oriented at being successful in the long run (De Waal, 2012). That is achieved in several ways. High performers maintain good and 
long-term relationships with all stakeholders (De Waal \& Meingast, 2017). They are aimed at servicing their customers as effectively as possible. The organisation grows through partnerships with suppliers and customers (De Waal, Mroueh, \& Schiavo, 2017). Longterm orientation is also achieved by a specific approach to human resource management. It aims at keeping managers and employees in the organisation for a long time which makes it a secure workplace for organisational members (De Waal \& Heijtel, 2017). Moreover, new managers are in most cases promoted from within the organisation rather than being hired from the outside (De Waal, van Nierop, \& Sloot, 2017).

\section{Entrepreneurial Orientation}

The base assumption for entrepreneurial orientation scale is that entrepreneurial firms differ from other types of firms (Khandwalla, 1977). They tend to take more risk than other types of firms, proactively search for new business opportunities and have strong emphasis on new product innovation (Khandwalla, 1977; Miller \& Friesen, 1982; Mintzberg, 1973). Some researchers operationalised the behaviour of entrepreneurial firms as consisting of productmarket innovation, proactiveness of decision making, and risk-taking (Lumpkin \& Dess, 1996). They maintained that the level of entrepreneurship presented by a firm is the aggregate total of these three sub-dimensions: 'the extent to which top managers are inclined to take business-related risks (the risk-taking dimension), to favour change and innovation in order to obtain a competitive advantage for their firm (the innovative dimension), and to compete aggressively with other firms (the proactive dimension)' (Covin \& Slevin, 1988, p. 218) These scholars also argued that a firm that is truly entrepreneurial should exhibit high levels of each dimension and that entrepreneurial orientation is linked to deeply stored cognitive processes (Palmié, Huerzeler, Grichnik, Keupp, \& Gassmann, 2019).

The most widely used operationalisation of the entrepreneurial orientation construct comes from Covin and Slevin (1989), based on Khandwalla (1977) and Miller and Friesen (1982). They stated that innovativeness, proactiveness and risk-taking act together creating uni-dimensional strategic orientation, and should be aggregated together. This assumption and the operationalisation itself proved reliable and valid in many studies, however, later works raised concern pertaining to the dimensionality of the measure and the independence of the sub-dimensions (Dess, Lumpkin, \& McGee, 1999; Lumpkin \& Dess, 1996; Zahra, 1993). As opposite to the unidimensional measure as constructed by Covin and Slevin (1989), a multi-dimensional measure reflecting each of the sub-dimensions was proposed (e.g. Lumpkin \& Dess, 1996). Proponents of the later approach argued that each sub-dimension of the entrepreneurial orientation construct uniquely contributes to the entrepreneurial process. They highlight the potential of each sub-dimension to have a different impact for key outcome variables such as firm performance (Lumpkin \& Dess, 2001).

Another important issue concerning entrepreneurial orientation is its validity for research in different countries. Formerly used constructs were developed originally for studies in the United States and then utilised for research in international entrepreneurship without adequately examining their validity. Steensma, Marino, Weaver and Dickson (2000) found that contemporary management theories may not be applicable in all international research contexts due to differences in national culture. Following this concern, Kreiser, Marino, and Weaver (2002) employed a multi-country sample to explore the cross-cultural validity of the entrepreneurial orientation construct. Their study provided strong support for the cross-cultural validity of this scale. Also Luu and Ngo (2019) found 
the entrepreneurial construct to be applicable in various cultural contexts, especially in transition economies. Moreover, EO has been successfully applied in various types of organisations, including public enterprises (Tremml, 2019) and also at an individual level (Kollmann, Stöckmann, Meves, \& Kensbock, 2017).

\section{Positive Deviance and its Capacity to Mediate The Relationship Between High Performance Indicators and Entrepreneurial Orientation}

Positive deviance is strongly grounded in 'positive' notions of the research: positive psychology and positive organisational scholarship. It has to be said that the expression 'deviance' is negatively attributed, which was highlighted by Dodge (1985). Deviations from norms can, however, be both positive and negative (Warren, 2003). The expression 'positive deviance' was originally used to describe the behaviour that was different from the standard one, contradictory to social norms, however socially desirable (Warren, 2003). In management science, it was used in a metaphorical way, in contrast to medical sciences, especially nutrition science, where the precise conceptualisations of positive deviance had been developed. In a POS perspective, positive deviance is a focus on extremely affirmative phenomena, significant exceptions from the norms to the positive side. It can refer to performance (individual or organisational) and ethical and moral positivity - behaviours that depart from norms but are perceived as positive (Spreitzer \& Sonnenshein, 2004).

Positive deviance has not been yet sufficiently conceptualised. It is also used by scholars in rather a loose manner (Vadera, Pratt, \& Mishra, 2013), ranging from describing departure from norms (Warren, 2003) to outcomes of certain type of leadership (Cameron, 2008; Williamson, Buchard, Winner, \& Winston, 2017). The critical role in conceptualising positive deviance is played by the work by Spreitzer and Sonenshein (2003; 2004). The explanation of positive deviance, its definition and operationalisation open the ground for further scholarly investigations. They claim that positive deviance is linked with meaning, prosocial motivation, self-determination, individual performance and courage and define it as 'intentional behaviour that significantly departs from norms of referent group in a way that is perceived as positive' (Spreitzer \& Sonenshein, 2004, 828). Positive scholars are consistent in a view that positive deviance has to be constructed in normative terms - to qualify the behaviour as positively deviant there has to be a group of people that consider that behaviour as positive from the point of view of their value system. There is, however, a problem with defining the point of reference - a social group that will value the behaviour. That problem concerns social groups at various levels of which some may consider the behaviour as positively deviant and other may not consider the behaviour as deviant at all (Kim \& Choi, 2018).

Spreitzer and Sonenshein (2003) also consider the contextual factors supporting positive deviance, such as transformational leadership or crisis management. Both seem to have positive influence on positively deviant behaviour. Some scholars also draw attention to possible consequences of positive deviance, such as subjective well-being, quality of relationship between a positive deviant and the recipient(s) of positively deviant behaviour, and individual and organisational performance (Cameron, 2008). Positive deviance plays also a role in changing the social norms (Kim \& Choi, 2018). Spreitzer and Sonenshein (2003) state that positively deviant behaviour creates a new norm, and behaviours that were in line with the previous norm begin to be perceived as negatively deviant. This way there is a shift in the norm towards the positive side. As a consequence, 
positive deviance has the potential to change not only the internal organisational reality but also external world through the connections of the organisations with stakeholders. It is also important to stress that positive deviance can be collective. Spreitzer and Sonenshein (2003) claim that it can be contagious and transfer from one person to another apart from creating new, more positive norms.

A completely different approach to positive deviance is presented by Cameron (2008) who presents a model of positive deviance with four dimensions: positive climate, positive relations, positive communication, positive meaning. Each of the components is created by certain activities: positive climate by fostering compassion, forgiveness and gratitude, positive relations by building energy networks and supporting strengths, positive communication by obtaining self-feedback and using supportive communication and positive meaning by creating well-being, appealing to personal values, promoting extended influence and building community. Cameron's concept, however interesting, is rather practical and business oriented as it lacks clarity and methodological rigour. Positive deviance has a wide meaning in this approach, it extends to a diversity of positive behaviours at work. However, what is unique in Cameron's concept is drawing attention to the significance of a leader in creating positive deviance.

There is some evidence that positive deviance might be linked to high performance factors. Cameron (2008) states that the process of organising itself is aimed at reducing deviance, therefore it is reasonable to assume that positive deviance will be supported by those of high performance indicators that stress constant change and development as opposite to maintaining status quo and stability. First of all, high performance factor 'continuous improvement' stresses the unique strategy, mission and vision and differentiation from other organisations that, by proxy, is deviant. High performing organisations are even different from others in terms of their perception of the purpose of their existence. Moreover, continuous improvement assumes introducing changes and innovations that also reflect positive deviance. Furthermore, factor 'openness and action orientation' promotes deviance as it stresses the permission to make mistakes and being open to change. Therefore, it can be hypothesised:

H1: High performance indicators positively influence positive deviance.

It is also very relevant to ask a question about the impact of positive deviance on organisational entrepreneurship. Intuitively, deviance is at the heart of entrepreneurship as it involves introducing changes, rapid changes in the way of thinking about the market and competition (Covin \& Slevin, 1988). Deviance is additionally related to all three dimensions of entrepreneurial orientation: innovativeness, proactiveness and risk taking (Lumpkin \& Dess, 2001). Especially innovativeness benefits from positively deviant behaviours, but also proactiveness is about doing things in a new way that is surprising for the competition and gaining competitive advantage this way (DeGraff \& Nathan-Roberts, 2012).

The relationship between positive deviance and organisational entrepreneurship and their components has been partly researched before. DeGraff and Nathan-Roberts (2012) claim that positive deviance is the essence of innovativeness. In addition, Nam, Parboteeah, Cullen and Johnson (2014) state that positive deviance is the antecedents of innovativeness. They also argue that some institutions at the country level can moderate that relationship. Kibirango, Munene, Balunywa and Obbo (2017) state that the 
relationship between positive deviance and organisational entrepreneurship is mediated by the ecosystem of novelty. Furthermore, Hartman, Wilson and Arnold (2005) link positive deviance to entrepreneurship and prove that two other phenomena are important for the co-existence of those two variables: visionary leadership and structures and actions that support the vision. It is consistent with the presented view that vision is the key to apply positive deviance at the strategic level. Hartman, Wilson and Arnold (2005) also highlight the role that is played by entrepreneurial firms using positive deviance. They state that those companies have a potential to change the rules of market competition and to rebuild the institutions in order to create new, higher ethical norms and better market standards. All of the above allow to hypothesise:

H2: Positive deviance positively influences entrepreneurial orientation.

The direct impact of high performance indicators on entrepreneurial orientation has been researched and proven before (Zbierowski, 2012). However, the hypothesised direct effect of high performance factors on positive deviance (Cameron, 2008; De Waal, 2012) and the hypothesised direct effect of positive deviance on entrepreneurial orientation (DeGraff \& Nathan-Roberts, 2012; Kibirango, Munene, Balunywa, \& Obbo, 2017) lead to formulating the hypothesis on the indirect impact of high performance indicators on organisational entrepreneurship:

H3: Positive deviance is the mediator in the relationship between high performance indicators and entrepreneurial orientation.

\section{MATERIAL AND METHODS}

\section{Research Design, Sample, Variables and Measures, Analytical Techniques}

The research was carried out in cross-sectional design on a random and representative sample of 406 Polish enterprises in 2017 and 2018. The research was carried out using the technique of personal interview (CAPI). In each enterprise two people were surveyed: senior manager (owner-manager or a member of the board if possible) and the direct subordinate of that person. Sampling was random and the sample frame was the database of Polish enterprises employing from 50 to 1000 employees. The choice to exclude small and very large enterprises was caused by the nature of the researched relationships. A couple of industries were excluded from the sampling: section A (PKD - Polish Classification of Activity) - farming, forestry, hunting and fishing, section $B$ - mining and extraction of natural resources, section $\mathrm{E}$ - water supply, sewage and waste management, recultivation, section $\mathrm{O}$ - public administration, national defence, obligatory social security, section $Q$ - healthcare and social support, section $\mathrm{T}$ - households employing workers, households producing goods and serving services for their own needs, section $U$ - exterritorial organisations and groups. Organisations in those sections run specific activity that could distort the research results.

To measure high performance factors the measure created by De Waal (2012) was used. Each of the dimensions was measured using three questions. Following Cronbach alpha reliability coefficients were calculated: continuous improvement $(0.877)$, openness and action orientation (0.762), management quality (0.836), workforce quality (0.825), long-term orientation (0.791). Positive deviance was measured using a simplified version of the measure proposed by Spreitzer and Sonenshein (2004). Each of the dimensions was 
measured using two items, dimensions were later aggregated to a single measure of positive deviance (0.932). Entrepreneurial orientation was measured using Kreiser, Marino and Weaver (2002) scale with three dimensions: innovativeness (three items, 0.842), proactiveness (three items, 0.834 ), risk taking (two items, 0.833). For high performance factors and entrepreneurial orientation the confirmatory factor analysis was conducted that confirmed the dimensionality of the constructs.

To test the hypotheses the full mediation modelling was chosen. To test the model further the bootstrapping procedure was used with 200 bootstrap samples and bias-corrected confidence level at $90 \%$. I used structural equations modelling to create and test the model, calculations were performed using SPSS AMOS 25 software. The bootstrapping procedure allows to test the statistical significance of mediated effects.

\section{RESULTS AND DISCUSSION}

The results of the full mediation model are presented in Figure 1 and Tables 1-5.

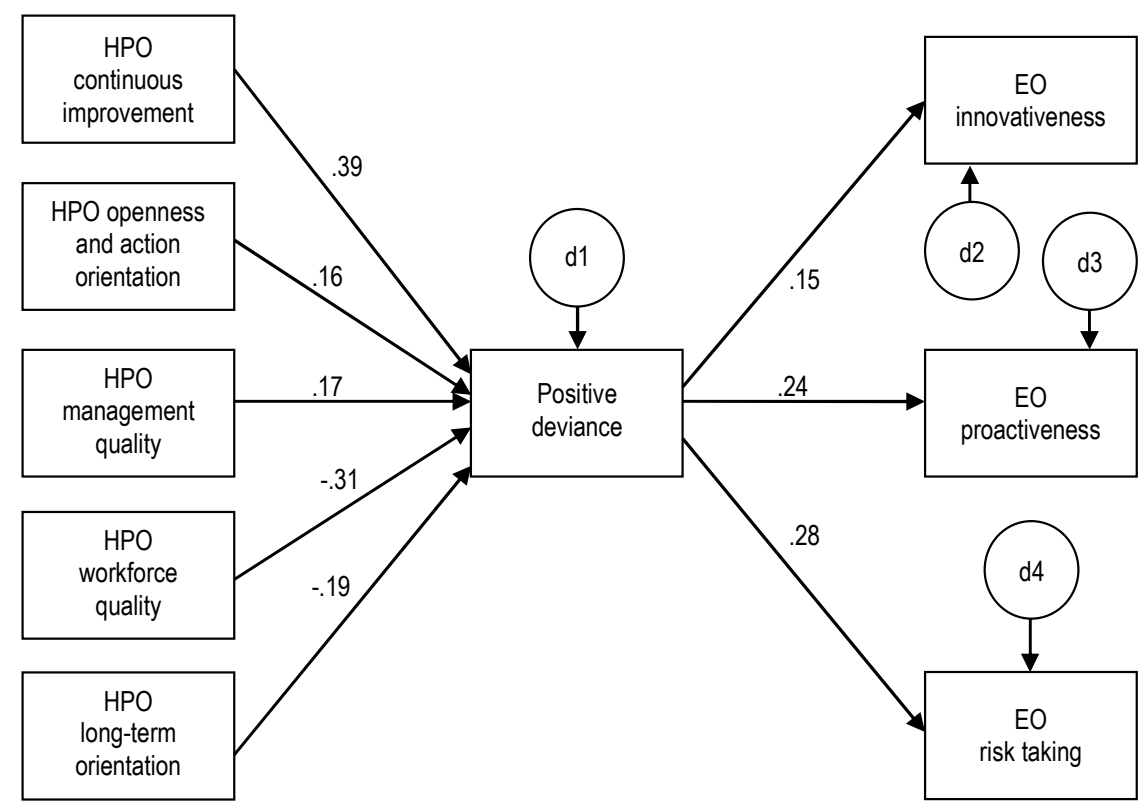

Figure 1. Mediation model with standardised weights of the effects

Source: own elaboration.

The results of the mediation analysis indicate the influence of all high performance factors on positive deviance, although the impact has various nature. Continuous improvement, openness and action orientation and management quality influence positive deviance in a positive way, while workforce quality and long-term orientation have a negative impact.

Positive deviance influences all three dimensions of entrepreneurial orientation in a positive way. The influence is a bit weaker for innovativeness and a bit stronger for other two dimensions: proactiveness and risk taking. Table 2 presents the exact standardised regression weights. 
Table 1. Regression weights

\begin{tabular}{|c|c|c|c|c|c|c|}
\hline \multicolumn{2}{|c|}{ Variables } & Estimate & S.E. & C.R. & P \\
\hline PD & $<---$ & HPO.LT.orient & -0.298 & 0.064 & -4.687 & $* * *$ \\
\hline PD & $<---$ & HPO.HR.quality & -0.502 & 0.065 & -7.739 & $* * *$ \\
\hline PD & $<---$ & HPO.man.quality & 0.262 & 0.064 & 4.105 & $* * *$ \\
\hline PD & $<---$ & HPO.open.action & 0.244 & 0.060 & 4.046 & $* * *$ \\
\hline PD & $<---$ & HPO.cont.improv & 0.525 & 0.054 & 9.685 & $* * *$ \\
\hline EO.proactiveness.lead & $<---$ & PD & 0.197 & 0.040 & 4.990 & $* * *$ \\
\hline EO.innovativeness.lead & $<---$ & PD & 0.134 & 0.044 & 3.011 & 0.003 \\
\hline EO.risk.taking.lead & $<---$ & PD & 0.230 & 0.040 & 5.828 & $* * *$ \\
\hline
\end{tabular}

Source: own study.

Table 2. Standardised regression weights

\begin{tabular}{|c|c|c|c|}
\hline \multicolumn{3}{|c|}{ Variables } & Estimate \\
\hline PD & $<---$ & HPO.LT.orient & -0.189 \\
\hline PD & $<---$ & HPO.HR.quality & -0.312 \\
\hline PD & $<---$ & HPO.man.quality & 0.166 \\
\hline PD & $<---$ & HPO.open.action & 0.163 \\
\hline PD & $<---$ & HPO.cont.improv & 0.391 \\
\hline EO.proactiveness & $<---$ & PD & 0.241 \\
\hline EO.innovativeness & $<---$ & PD & 0.148 \\
\hline EO.risk.taking & $<---$ & PD & 0.278 \\
\hline
\end{tabular}

Source: own study.

The strongest relationships in the model concern the negative impact of workforce quality on positive deviance and the positive impact of continuous improvement on positive deviance. Tables 3-5 present standardised total, direct and indirect effects.

Table 3. Standardised total effects

\begin{tabular}{|l|c|c|c|c|c|c|}
\hline \multicolumn{1}{|c|}{ Variables } & $\begin{array}{c}\text { HPO.cont.i } \\
\text { mprov }\end{array}$ & $\begin{array}{c}\text { HPO.open. } \\
\text { action }\end{array}$ & $\begin{array}{c}\text { HPO.man. } \\
\text { quality }\end{array}$ & $\begin{array}{c}\text { HPO.HR.qu } \\
\text { ality }\end{array}$ & $\begin{array}{c}\text { HPO.LT.ori } \\
\text { ent }\end{array}$ & PD \\
\hline PD & 0.391 & 0.163 & 0.166 & -0.312 & -0.189 & 0.000 \\
\hline EO.risk.taking & 0.109 & 0.045 & 0.046 & -0.087 & -0.053 & 0.278 \\
\hline EO.innovativeness & 0.058 & 0.024 & 0.025 & -0.046 & -0.028 & 0.148 \\
\hline EO.proactiveness & 0.094 & 0.039 & 0.040 & -0.075 & -0.046 & 0.241 \\
\hline
\end{tabular}

Source: own study.

Table 4. Standardised direct effects

\begin{tabular}{|l|c|c|c|c|c|c|}
\hline \multicolumn{1}{|c|}{ Variables } & $\begin{array}{c}\text { HPO.cont.i } \\
\text { mprov }\end{array}$ & $\begin{array}{c}\text { HPO.open. } \\
\text { action }\end{array}$ & $\begin{array}{c}\text { HPO.man. } \\
\text { quality }\end{array}$ & $\begin{array}{c}\text { HPO.HR.qu } \\
\text { ality }\end{array}$ & $\begin{array}{c}\text { HPO.LT.ori } \\
\text { ent }\end{array}$ & PD \\
\hline PD & 0.391 & 0.163 & 0.166 & -0.312 & -0.189 & 0.000 \\
\hline EO.risk.taking & 0.000 & 0.000 & 0.000 & 0.000 & 0.000 & 0.278 \\
\hline EO.innovativeness & 0.000 & 0.000 & 0.000 & 0.000 & 0.000 & 0.148 \\
\hline EO.proactiveness & 0.000 & 0.000 & 0.000 & 0.000 & 0.000 & 0.241 \\
\hline
\end{tabular}

Source: own study. 
Table 5. Standardised indirect effects

\begin{tabular}{|l|c|c|c|c|c|c|}
\hline \multicolumn{1}{|c|}{ Variables } & $\begin{array}{c}\text { HPO.cont } \\
\text {.improv }\end{array}$ & $\begin{array}{c}\text { HPO.ope } \\
\text { n.action }\end{array}$ & $\begin{array}{c}\text { HPO.man } \\
\text {.quality }\end{array}$ & $\begin{array}{c}\text { HPO.HR.q } \\
\text { uality }\end{array}$ & $\begin{array}{c}\text { HPO.LT.o } \\
\text { rient }\end{array}$ & PD \\
\hline PD & 0.000 & 0.000 & 0.000 & 0.000 & 0.000 & 0.000 \\
\hline EO.risk.taking & 0.109 & 0.045 & 0.046 & -0.087 & -0.053 & 0.000 \\
\hline $\begin{array}{l}\text { EO.innovative- } \\
\text { ness }\end{array}$ & 0.058 & 0.024 & 0.025 & -0.046 & -0.028 & 0.000 \\
\hline EO.proactiveness & 0.094 & 0.039 & 0.040 & -0.075 & -0.046 & 0.000 \\
\hline
\end{tabular}

Source: own study.

Because the model does not include any direct and indirect effects of any two variables the total effect of high performance factors on dimensions of entrepreneurial orientation are equal to the indirect effects and total effects of high performance factors on positive deviance and of positive deviance on dimensions of entrepreneurial orientation are equal to the direct effects. The total (and indirect) effects of high performance indicators on entrepreneurial orientation are not very strong, the highest positive effects concern the impact of continuous improvement on risk taking and proactiveness and the strongest negative impact was observed for the influence of workforce quality on risk taking.

The statistical significance of the obtained results was tested by bootstrapping. For this procedure the number of bootstrap samples was 200 and bias-corrected confidence level was set at $90 \%$. The statistical significance was then tested in bias corrected percentile method by comparison of lower bounds and upper bounds in standardised total effects, standardised direct effects and standardised indirect effects. The results are presented in Tables 6-8.

Table 6. Standardised total effects

\begin{tabular}{|l|c|c|c|c|c|c|}
\hline \multicolumn{1}{|c|}{ Variables } & $\begin{array}{c}\text { HPO.cont.i } \\
\text { mprov }\end{array}$ & $\begin{array}{c}\text { HPO.open. } \\
\text { action }\end{array}$ & $\begin{array}{c}\text { HPO.man. } \\
\text { quality }\end{array}$ & $\begin{array}{c}\text { HPO.HR.qu } \\
\text { ality }\end{array}$ & $\begin{array}{c}\text { HPO.LT.ori } \\
\text { ent }\end{array}$ & PD \\
\hline \multicolumn{7}{|c|}{ Lower bounds } \\
\hline PD & 0.276 & 0.013 & 0.042 & -0.447 & -0.311 & 0.000 \\
\hline EO.risk.taking & 0.052 & 0.005 & 0.016 & -0.137 & -0.090 & 0.168 \\
\hline EO.innovativeness & 0.012 & 0.006 & 0.006 & -0.081 & -0.060 & 0.033 \\
\hline EO.proactiveness & 0.036 & 0.010 & 0.011 & -0.115 & -0.080 & 0.122 \\
\hline \multicolumn{7}{|c|}{ Upper bounds } \\
\hline PD & 0.488 & 0.304 & 0.269 & -0.172 & -0.062 & 0.000 \\
\hline EO.risk.taking & 0.170 & 0.090 & 0.086 & -0.046 & -0.015 & 0.371 \\
\hline EO.innovativeness & 0.105 & 0.068 & 0.053 & -0.015 & -0.007 & 0.241 \\
\hline EO.proactiveness & 0.154 & 0.088 & 0.080 & -0.039 & -0.010 & 0.326 \\
\hline
\end{tabular}

Source: own study.

The bootstrapping procedure proves that all of the direct, indirect and total effects are statistically significant with the confidence level of $90 \%$. The above results provide partial support for hypothesis $\mathrm{H} 1$, full support for hypotheses $\mathrm{H} 2$ and $\mathrm{H} 3$.

The study revealed the existence of a couple of interesting relationships between the variables. First of all, the impact of high performance indicators on positive deviance is somehow ambiguous. Some of the factors influence positive deviance in a positive way 
(continuous improvement, openness and action orientation, management quality) and some in a negative way (workforce quality, long-term orientation). To explain that the content of those factors should be investigated. Factor 'continuous improvement' concerns mainly improving processes and introducing innovations. This definitely supports positive deviance as it involves constant change. Moreover, the strategy of high performers puts stress on differentiation, therefore any deviant approaches are promoted as they are not likely to be manifested by competitors. Factor 'openness and action orientation' includes allowing employees to make mistakes and welcoming change by the firm's management. Both indicators are important for positive deviance. Positively deviant behaviours might be risky as the outcomes are difficult to predict. Therefore, being open to change and allowing to make mistakes promotes positively deviant behaviours. Also spending a lot of time on dialogue and knowledge exchange helps to build the climate of trust, where positively deviant behaviours are more likely to be expressed. Factor 'management quality' also stresses the role of trust, moreover, it highlights being a role model by the manager and fast decision making and acting. Those factors also contribute to positive deviance by creating a dynamic, yet secure environment.

Table 7. Standardised direct effects

\begin{tabular}{|l|c|c|c|c|c|c|}
\hline \multicolumn{1}{|c|}{ Variables } & $\begin{array}{c}\text { HPO.cont.i } \\
\text { mprov }\end{array}$ & $\begin{array}{c}\text { HPO.open. } \\
\text { action }\end{array}$ & $\begin{array}{c}\text { HPO.man. } \\
\text { quality }\end{array}$ & $\begin{array}{c}\text { HPO.HR.qu } \\
\text { ality }\end{array}$ & $\begin{array}{c}\text { HPO.LT.ori- } \\
\text { ent }\end{array}$ & PD \\
\hline \multicolumn{7}{|c|}{ Lower bounds } \\
\hline PD & 0.276 & 0.013 & 0.042 & -0.447 & -0.0311 & 0.000 \\
\hline EO.risk.taking & 0.000 & 0.000 & 0.000 & 0.000 & 0.000 & 0.168 \\
\hline EO.innovativeness & 0.000 & 0.000 & 0.000 & 0.000 & 0.000 & 0.033 \\
\hline EO.proactiveness & 0.000 & 0.000 & 0.000 & 0.000 & 0.000 & 0.122 \\
\hline \multicolumn{7}{|c|}{ Upper bounds } \\
\hline PD & 0.488 & 0.304 & 0.269 & -0.172 & -0.062 & 0.000 \\
\hline EO.risk.taking & 0.000 & 0.000 & 0.000 & 0.000 & 0.000 & 0.371 \\
\hline EO.innovativeness & 0.000 & 0.000 & 0.000 & 0.000 & 0.000 & 0.241 \\
\hline EO.proactiveness & 0.000 & 0.000 & 0.000 & 0.000 & 0.000 & 0.326 \\
\hline
\end{tabular}

Source: own study.

Table 8. Standardised indirect effects

\begin{tabular}{|l|c|c|c|c|c|c|}
\hline \multicolumn{1}{|c|}{ Variables } & $\begin{array}{c}\text { HPO.cont.i } \\
\text { mprov }\end{array}$ & $\begin{array}{c}\text { HPO.open. } \\
\text { action }\end{array}$ & $\begin{array}{c}\text { HPO.man. } \\
\text { quality }\end{array}$ & $\begin{array}{c}\text { HPO.HR.qu } \\
\text { ality }\end{array}$ & $\begin{array}{c}\text { HPO.LT.ori } \\
\text { ent }\end{array}$ & PD \\
\hline \multicolumn{7}{|c|}{ Lower bounds } \\
\hline PD & 0.000 & 0.000 & 0.000 & 0.000 & 0.000 & 0.000 \\
\hline EO.risk.taking & 0.052 & 0.005 & 0.016 & -0.137 & -0.090 & 0.000 \\
\hline EO.innovativeness & 0.012 & 0.006 & 0.006 & -0.081 & -0.060 & 0.000 \\
\hline EO.proactiveness & 0.036 & 0.010 & 0.011 & -0.115 & -0.080 & 0.000 \\
\hline \multicolumn{7}{|c|}{ Upper bounds } \\
\hline PD & 0.000 & 0.000 & 0.000 & 0.000 & 0.000 & 0.000 \\
\hline EO.risk.taking & 0.170 & 0.090 & 0.086 & -0.046 & -0.015 & 0.000 \\
\hline EO.innovativeness & 0.105 & 0.068 & 0.053 & -0.015 & -0.007 & 0.000 \\
\hline EO.proactiveness & 0.154 & 0.088 & 0.080 & -0.039 & -0.010 & 0.000 \\
\hline
\end{tabular}

Source: own study. 
The negative impact of two of high performance factors on positive deviance is somehow unexpected. However, a closer look at the content of two high performance factors helps to uncover the meaning of the relationship. In 'workforce quality' the stress is put on taking responsibility by employees and being resilient. This promotes rather a static view of organisational activities and does not support positive deviance very well. Similarly, for 'long-term orientation' it is critical that the organisation maintains good relationships with the stakeholders and that the organisation is a secure workplace (including keeping employees for a long time and internal selection of managers). I argue that good relationships with the stakeholders are based on predictability that contradicts positive deviance. Also job security is not well suited with positively deviant behaviours.

As predicted, positive deviance positively influences all three dimensions of entrepreneurial orientation. However, rather unexpectedly, it has the weakest influence on innovativeness, which relationship is most evidenced in the literature. The impact of positive deviance on proactiveness and risk taking is less documented but the conducted research shows that it is stronger. Positively deviant behaviours might be surprising for competitors, they constitute new ways of thinking not known to other companies. Therefore, proactiveness may have its source in them. Positively deviant behaviours are also risky as they may require the allocation of resources and the final result is rather difficult to predict. Therefore, positive deviance results in higher risk.

The study revealed a general indirect effect of high performance factors on dimensions of entrepreneurial orientation with the mediation of positive deviance. All of the mediated relationships are statistically significant, however, all of them are rather weak. However, some of them are worth discussing. The strongest positive impact $(0.109)$ is by 'continuous improvement' on risk taking. Similarly to positive deviance, constant improvement involves taking decisions on the allocation of resources that are risky and new solutions are not guaranteed to be successful. 'Continuous improvement' has also a positive impact on proactiveness (0.094). Introducing changes leads to gaining competitive advantage not necessarily by product innovation but also by improving, simplifying and aligning processes.

The strongest negative indirect impact of high performance factors on entrepreneurial orientation dimensions was observed for 'workforce quality' and risk taking (-0.087) and proactiveness $(-0.075)$. Both relationships are caused by stability and security that are promoted in that high performance factor. They prevent both taking risk and proactive behaviours of employees and the whole organisation. To sum up, the influence of high performance factors on entrepreneurial orientation is mixed with the slight dominance of the positive impact.

\section{CONCLUSIONS}

The research on positive deviance is growing especially in relation to leadership and teamwork (Cameron, 2008; Williamson, Buchard, Winner, \& Winston, 2017; Kim \& Choi, 2018). The present study contributes to this line of literature by pointing to the role of positive deviance in mediating between operational strategies employed by companies and outcomes, such as entrepreneurial orientation that leads to higher performance (Lumpkin \& Dess, 1996). The contribution is especially relevant in considering the organisation-level effects of positive deviance, contrary to the effect at the team level, most commonly investigated recently (Williamson, Buchard, Winner, \& Winston, 2017; Kim \& Choi, 2018). 
Another contribution is the discovery of ambiguities regarding the outcomes of high performance indicators. Until now, all of them have been presented as resulting in positive consequences and higher performance (De Waal, 2012). The results contradict that view and point to some possible negative outcomes of being driven by high performance. Moreover, it seems that the construct of high performance indicators is internally contradictory and demands agility to be properly implemented.

The study also contributes to the stream of research on entrepreneurial orientation at organisational level, and more broadly to research on organisational entrepreneurship, corporate entrepreneurship and intrapreneurship. The results contribute especially to research on cognition and behaviours related to entrepreneurial orientation (Palmié et al., 2019) by pointing to some effects of positively deviant cognitive and behavioural processes on entrepreneurial orientation. Furthermore, the present study is relevant for the configuration of high performance features and entrepreneurial orientation in some specific types of organisations, such as public enterprises (Tremml, 2019). The results of the study are especially relevant for developing and transition economies (Luu \& Ngo, 2019).

Finally, the study contributes to the development of research stream of high performance organisation attributes (De Waal, 2010; De Waal, 2012; De Waal, van Nierop, \& Sloot, 2017; De Waal \& Heijtel, 2017; De Waal \& Meingast, 2017; De Waal, Mroueh, \& Schiavo, 2017), especially by at least partly explaining how high performance characteristics drive entrepreneurial orientation, and ultimately, high performance.

The key recipients of the results of the study are CEOs and senior managers involved in day-to-day running of businesses. In their interest is the enhancement of entrepreneurial orientation as a tool to gain competitive advantage and high performance (Lumpkin \& Dess, 1996). There are a couple of practical recommendations that can be drawn from the results of the study. First of all, positive deviance is a good way of supporting entrepreneurial orientation. Therefore, companies that are in pursuit of higher organisational entrepreneurship can use it as a good way of supporting it. It concerns all aspects of entrepreneurial orientation, especially proactiveness. By promoting non-standard behaviours companies can therefore surprise customers and gain first-mover advantage. Another practical recommendation concerns shaping the high performance factors to support both positive deviance and organisational entrepreneurship. It seems that some of them should be maximised, like constant improvement, creating extraordinary vision, mission and strategy, allowing to make mistakes, welcoming change, fast decision making and action and integral, strong and confident leadership. All of the above behaviours support positive deviance and, in consequence, organisational entrepreneurship. By contrast, organisations should be careful with using some other high performance indicators grouped in factors 'workforce quality' and 'long-term orientation'. It seems that those factors introduce high level of stability that can be harmful to positively deviant behaviours. The answer to that might be the reconciliation of contradiction between stability and flexibility, organisations should make the environment as friendly to employees and at the same time encourage them to be flexible.

Apart from CEOs and senior managers the stakeholders of the present study results are employees. Positive deviance is associated with a wide range of other positive behaviours, such as taking charge, creative performance, expressing voice, whistle-blowing, extra-role behaviours, prosocial behaviors, prosocial rule breaking, counter-role behaviours, and issue selling (Vadera, Pratt, \& Mishra, 2013). Therefore, promoting positive deviance 
by using high performance characteristics will lead not only to higher levels of entrepreneurial orientation but also to positive workplace actions that ultimately lead to higher satisfaction and well-being (Weinstein \& Ryan, 2010).

There are some limitations to the study. One of them is of conceptual nature: the proposed model does not include any direct relationships between high performance indicators and dimensions of entrepreneurial orientation. The reason for that is twofold. First, that relationship has been researched before (Zbierowski, 2012) and second, including direct relationships would blur the model by adding 15 additional effects which would make the framework difficult to comprehend and interpret. However, as a result of that, it is impossible to predict if indirect relationships are stronger than direct ones and therefore if the relationship is fully or only partially mediated. The other limitation is the sample that is homogeneous in terms of nationality which might make the results country specific and difficult to generalise. Therefore, future empirical investigations in that notion could take into consideration larger, international samples and/or replicating the research. Moreover, in spite of the question about 'how' high performance indicators work there is still space to investigate possible mediators in the relationships between them and their outcomes.

\section{REFERENCES}

Cameron, K.S. (2008). Positive leadership. Strategies for extraordinary performance. San Francisco: Berrett Koehler.

Collins, J.C., \& Porras, J.I. (1994). Built to last. Successful habits of visionary companies. New York: Harper Business.

Collins, J.C. (2001). Good to great: why some companies make the leap... and others don't. New York: Harper Business.

Covin, J.G., \& Slevin, D.P. (1988). The influence of organisation structure on the utility of an entrepreneurial top management style. Journal of Management Studies, 25(3), 217-234.

Covin, J.G., \& Slevin, D.P. (1989) Strategic management of small firms in hostile and benign environments. Strategic Management Journal, 10(1), 75-87.

De Waal, A.A. (2010). Achieving high performance in the public sector: What needs to be done?. Public Performance \& Management Review, 34(1), 81-103.

De Waal, A.A. (2012). Characteristics of high performance organisations. Business Management and Strategy, 3(1), 28-45.

De Waal, A., van Nierop, E., \& Sloot, L. (2017). Analysing supermarket performance with the highperformance organisation framework. International Journal Of Retail \& Distribution Management, 45(1), 57-70.

De Waal, A., \& Heijtel, I. (2017). Developing a change approach for the transition to a high performance organization. Measuring Business Excellence, 21(2), 101-116.

De Waal, A., \& Meingast, A. (2017). Applying the high performance organisation framework in the horticulture and greenhouse sector. Measuring Business Excellence, 21(2), 136-151.

De Waal, A., Mroueh, M., \& Schiavo, L. (2017). Analyzing performance in the UAE manufacturing industry using the high performance organization framework. Middle East Journal of Business, 12(1), 3-11.

DeGraff, J., \& Nathan-Roberts, D. (2012). Innovativeness as positive deviance. Identifying and operationalizing the attributes, functions and dynamics that create growth. In K.S. Cameron, J.E. 
Dutton \& R.E. Quinn (Eds.) Positive organisational Scholarship, Foundations of a new discipline (pp. 703-714), San Francisco: Berrett-Koahler Publishers, Inc.

Dodge, D. (1985). The over-negativized conceptualization of deviance: A programmatic exploration. Deviant Behaviour, 6(1), 17-37.

Hartman, L., Wilson, F., \& Arnold, D. (2005). Positive ethical deviance inspired by moral imagination. Zeitschrift Fuer Wirtschafts- Und Unternehmensethik, 6(3), 343-358.

Holbeche, L. (2005). The high performance organisation. Creating dynamic stability and sustainable success. Oxford: Elsevier/Butherworth Heinemann.

Khandwalla, P.N. (1977). The design of organisations. New York: Harcourt Brace Janovich.

Kibirango, M., Munene, J., Balunywa, W., \& Obbo, J. (2017). Mediation effect of novelty ecosystems on intrapreneurial behaviour process within an organisational dynamic environment among Kenyan universities. Journal Of Organisational Change Management, 30(6), 957-977.

Kim, M.J., \& Choi, J.N. (2018). Group identity and positive deviance in work groups. Journal of Social Psychology, 158(6), 730-743.

Kollmann, T., Stöckmann, C., Meves, Y., \& Kensbock, J. (2017). When members of entrepreneurial teams differ: linking diversity in individual-level entrepreneurial orientation to team performance. Small Business Economics, 48(4), 843-859.

Kreiser, P.M., Marino L., \& Weaver, K.M. (2002). Assessing the psychometric properties of the entrepreneurial orientation scale: A multi-country analysis. „Entrepreneurship Theory and Practice, 26(4), 71-94.

Lawler, E.E. III, \& Worley, C.G. (2006). Built to change. How to achieve sustained organisational effectiveness. San Francisco: Jossey-Bass.

Light, P.C. (2005). The four pillars of high performance. How robust organisations achieve extraordinary results. New York: McGraw-Hill.

Lumpkin, G.T., \& Dess G.G. (2001). Linking two dimensions of entrepreneurial orientation to firm performance: The moderating role of environment and industry life cycle. Journal of Business Venturing, 16(5), 429-451.

Lumpkin, G.T., \& Dess, G.G. (1996). Clarifying the entrepreneurial orientation construct and linking it to performance. Academy of Management Journal, 21(1), 135-172.

Luu, N., \& Ngo, L.V. (2019). Entrepreneurial orientation and social ties in transitional economies. Long Range Planning, 52(1), 103-116

Miller, D., \& Friesen, P.H. (1982). Innovation in conservative and entrepreneurial firms: Two models of strategic momentum. Strategic Management Journa, 3(1), 1-25.

Miller, D., \& Le Breton-Miller, J. (2005). Managing for long run. Lessons in competitive advantage from great family businesses. Boston: Harvard Business School Press.

Mintzberg, H. (1973). Strategy-making in three modes. California Management Review, 16(2), 44-53.

Nam, D., Parboteeah, K., Cullen, J., \& Johnson, J. (2014). Cross-national differences in firms undertaking innovation initiatives: An application of institutional anomie theory. Journal of International Management, 20(2), 91-106.

Palich, L.E., \& Bagby, D.R. (1995). Using cognitive theory to explain entrepreneurial risk-taking: Challenging conventional wisdom. Journal of Business Venturing, 10(6), 425-438.

Palmié, M., Huerzeler, P., Grichnik, D., Keupp, M.M., \& Gassmann, O. (2019). Some principles are more equal than others: Promotion- versus prevention-focused effectuation principles and their disparate relationships with entrepreneurial orientation. Strategic Entrepreneurship Journal, 13(1), 93-117. 
Peters, T.J., \& Waterman, R.H. (1982). In search of excellence: Lessons from America's best-run companies. New York: Harper \& Row.

Spreitzer, G., \& Sonenshein, S. (2004). Toward a construct definition of positive deviance. American Behavioural Scientist, 47(6), 828-847.

Spreitzer, G.M., \& Sonenshein, S. (2003). Positive deviance and extraordinary organizing. In K.S. Cameron, J.E. Dutton, \& R.E. Quinn (Eds.), Positive organisational Scholarship. Foundations of a new discipline (pp. 207-224), San Francisco: Berrett-Koahler Publishers, Inc.

Tremml, T. (2019). Linking Two Worlds? Entrepreneurial Orientation in Public Enterprises: A Systematic Review and Research Agenda. Annals of Public \& Cooperative Economics, 90(1), 25-51.

Vadera, A.K., Pratt, M.G., \& Mishra, P. (2013). Constructive Deviance in Organizations: Integrating and Moving Forward. Journal of Management, 39(5), 1221-1276.

Warren, D. (2003). Constructive and destructive deviance in organisations. Academy of Management Review, 28(4), 622-632.

Weinstein, N., \& Ryan, R.M. (2010). When Helping Helps: Autonomous Motivation for Prosocial Behavior and Its Influence on Well-Being for the Helper and Recipient. Journal of Personality \& Social Psychology, 98(2), 222-244.

Williamson, B., Buchard, M., Winner, W.D., \& Winston, B.E. (2017). Internal Factors That Enable Positive Deviance to Occur in Leaders: A Phenomenological Description. International Leadership Journal, 9(1), 30-55.

Zbierowski, P. (2012). Orientacja pozytywna organizacji wysokiej efektywności. Warszawa: Wolters Kluwer. 


\section{Author}

\section{Przemysław Zbierowski}

Associate Professor at the Department of Human Resource Management, Faculty of Management, University of Economics in Katowice. Research focus: entrepreneurship, psychology of entrepreneurship, positive organizational behaviour.

Correspondence to: Prof. UE, dr hab. Przemysław Zbierowski, University of Economics in Katowice, Department of Human Resources Management, ul. Bogucicka 3a (Building B, office 412), 40-226 Katowice, Poland, e-mail: przemyslaw.zbierowski@ue.katowice.pl

ORCID (i) http://orcid.org/0000-0001-6144-1940

\section{Acknowledgements and Financial Disclosure}

The research was carried out within the research project 2014/13/B/HS4/01618 funded by the National Science Centre, Poland.

\section{Copyright and License}

This article is published under the terms of the Creative Commons

Attribution - NoDerivs (CC BY-ND 4.0) License

http://creativecommons.org/licenses/by-nd/4.0/

Published by the Centre for Strategic and International Entrepreneurship - Krakow, Poland 
